\title{
Paper Plants in the Tibetan World: A Preliminary Study
}

\author{
Alessandro Boesi
}

Tibetan texts, notably religious ones (dpe cha), were inspired by Indian Buddhist manuscripts, which were produced from palm leaves, ${ }^{1}$ and represented one of the oldest tools of writing in India, and several other Asian Countries as Thailand, Burma, Nepal, and Sri Lanka. Called grantha or later pustaka, they were manufactured in the so-called pothi format - loose long rectangular leaves held together by a string that runs through holes in the middle and then bound around with two covers, usually made of wood. Tibetan manuscripts and printed texts mostly conserve the Indian pothi format.

In the seventh century, when Tibet became a powerful empire in Asia and the basis of Tibetan civilization were laid, recording of information became a crucial undertaking, primarily for administrative and ritual purposes. A new script based on a Sanskrit alphabet was devised; stone inscriptions were carved and wood was often used as writing surface but had significant limitations. As paper, and techniques for making it, were imported from neighbouring countries much more extensive writing became possible. It was most likely during this period that Tibetans selected the local plants that could be used to produce paper, and started this activity in their own country.

The aim of this article is to examine paper plants in the Tibetan cultural area, particularly focusing on their identification. This will be done by examining accounts from pre-modern Tibet, my field data, research data, and the information available on Tibetan medical treatises. This study is preliminary.

Research specifically addressing the issue of Tibetan paper plants is rare and only recently scholars have attempted to deal with this subject (HelmanWażny and Van Schaik 2013). At present we still do not know precisely which plant species have been used in the past and are used today in each region and printing house, which are the areas of collection of these plants, and which

1 According to Agrawal (1984: 25-27), the leaves of only a few varieties of palm-trees have been used for writing in South and Southeast Asia. The most widely exploited species included Borassus flabellifer Linn (the Palmyra palm), Corypha umbraculifera Linn (talipot, fan palm), and Corypha taliera Roxb.

(C) ALESSANDRO BOESI, 2016 | DOI 10.1163/9789004316256_024

This is an open access chapter distributed under the terms of the Creative Commons Attribution- 
regions and places have represented the main centres of paper production. Also, we do not know how local people perceive, categorize these plants, evaluate their qualities as raw materials for paper-making, and it is not clear to what extent these plants were and are significant for the life of Tibetans, notably in the context of the exploitation and marketing of natural resources. At present we know for certain that the main raw materials used for paper production in Tibet have been obtained from Daphne, Edgeworthia, Stellera, and Wikstroemia species of the Thymelaeaceae family.

Several travellers, explorers, and missionaries who lived and criss-crossed Tibetan cultural regions in the past centuries reported the use of certain plants for paper manufacture.

Waddell (1905: 226), who participated in the Younghusband military expedition to Lhasa in 1904, wrote that at the rGyal rtse sKu 'bum, "The books are usually written on a paper made from the bark of the Himalayan laurel or the root-fibre of a native lint like plant." The former plant likely corresponds to Daphne and Wikstroemia species or to Edgeworthia gardneri.

Eric Teichman (1922: 107), the British consular officer who extensively travelled in eastern Tibet in 1918, when passing through Nang chen in northeast Tibet, reported: "I came across some Tibetans digging up the root of a kind of bush from which Tibetan paper is made. This paper is used all over Tibet. The Chinese locally call it p'ichih ('skin paper' - there are also other kinds of p'ichih made in China). It is very tough and strong, but, in Eastern Tibet at any rate, so roughly made as to be difficult to write upon with a steel pen; the Tibetan wooden pen, however, slides over the obstructions of unassimilated fragments of wood and straw more successfully." So according to Teichman this root, certainly obtained from Stellera chamaejasme, was used as source material to produce paper, and this paper was used all over Tibet. The quality of the paper produced in this area, which Teichman deemed to be low, possibly depended upon local procedures and skills. Actually, according to Trier (1972: 56) "paper made from the bast of Wikstroemia chamaejasme [synonym for Stellera chamaejasme] was regarded as of high quality in Tibet and used for special purposes as paper money".

Beetham, ${ }^{2}$ who participated in the British expedition to Everest in 1924, took some very interesting pictures of people from the Rong shar Valley, located to

2 See The Bentley Beetham Collection: http://www.bentleybeetham.org/index.php. 
the west of Everest region, while working on paper production, and notably peeling off the bark of local plants, making paper pulp, and putting paper to dry on moulds. Beetham wrote that this paper was made from elder (Sambucus sp.) bark. To my knowledge species belonging to this genus, two of which are present in Tibet (S. adnata and S. javanica) (Wu et al. 2011, 19: 611-613), have never been used for making paper. So it must be again species belonging to the Thymelaeaceae family (see below). Beetham also commented that the paper would end up in Lhasa, where it was used for official purposes.

The British officer Samuel Turner (1800: 99-100) described the process of papermaking in Bhutan in the mid-18th century: "In our perambulations down the valley, I often rested at the place where the chief manufacture of paper is established, which was made, I found, by a very easy and inexpensive process, of the bark of a tree, here called Deah, which grows in great abundance upon the mountains near Tassuisudon, but is not produced on those immediately bordering on Bengal." The term 'Deah' likely relates to the Dzonkha language designation "De shing" that, according to a FAO report on plant use in Bhutan (Chamling 1996: 44), indicates both Edgeworthia gardneri and Daphne bholua (Table 3).

A few works indicate that in sDe dge (sDe dge County in dKar mdzes Tibetan Autonomous Prefecture, Sichuan Province, PRC), locality hosting one of the most important printing houses of Tibet, the plant mainly used for papermaking has been Stellera chamaejasme. Duncan (1964: 64), a missionary who lived in 'Ba thang from 1921 to 1932, reported that, "After the root pulp has been washed and spread thinly on cloth stretched between frames it is dried in the sun assuming the form of paper sheets. This is an important business at sDe dge." Also at the present time according to Dongfa (2010: $7^{8-79)}$ at sDe dge, "The paper was made from the root tassels of the local medical herbal plant. [Stellera chamaejasme] Therefore, the paper had the characteristics of being anti-vermin and worms and of good fibre quality for long term preservation."

\section{$2 \quad$ Recent Research}

During my research fieldwork many informants from different Tibetan regions as Li thang County (dKar mdzes Autonomous Prefecture, Sichuan Province, PRC), lower Mustang District and Dhorpatan (Baglung District) in Nepal, Lhasa area (TAR, PRC), Reb kong (Tongren County, Huangnan Tibetan Autonomous Prefecture, Qinghai Province, PRC) and Bla brang (Gannan Tibetan Autonomous prefecture, Xiahe County, Gansu Province, PRC) in A mdo, have reported that in the past paper was made by using plant bark 
(obtained either from stem or root), which was beaten to obtain paper pulp, mixed with water, and spread over a mould to dry.

The first time that I was shown a plant that Tibetans have used to produce paper was in 1999. At that time I was conducting my $\mathrm{PhD}$ research fieldwork in Li thang, a Tibetan town located in eastern Tibetan regions. Ngag dbang bkra shis, a local traditional doctor, indicated me a plant abundantly growing over the southern slopes of spom ra, the mountain dominating Lithang, which he collected and used to prepare medicines, particularly to relieve pain, to treat swellings, infectious, and skin diseases. Ngag dbang bkra shis commented that the root of this plant, named re lcag pa (Stellera chamaejasme) $)^{3}$ according to Tibetan medical treatises, and $m g$ o re lcag re in the local dialect, was used for making paper before the arrival of the Chinese in the 1950s. Not far from the place where we stood near Li thang monastery Ngag dbang bkra shis also showed me a ruined building that once was Li thang printing house.

According to my field data, Stellera chamaejasme is a well-known paperplant in many Tibetan cultural regions: in A mdo, Khams, and dBus gtsang, and in Nepalese high valleys as Dolpo and lower Mustang. Tibetans generally designate this plant shog gu me tog ('paper flowering plant'), shog ldum ('paper plant'), and shog shing ('paper wood'), and use these same designations to indicate the other plants locally exploited for paper-making. Yet in each region a local vernacular name for Stellera is used, as mgo re lcag re at Lithang, $m g o$ na $r a$ in Nepalese Dolpo, mgo bo rol gdangs in lower Mustang District (Nepal), and ra ma rwa co in Xining area (Qinghai Province, PRC). According to a recent ethnobotanical study (Ji et al. 2000) conducted in northwest Yunnan, Stellera chamaejasme was used as indigenous medicine, virulent herb, pesticide, and raw material for making paper in the area.

It is interesting to note that Tibetans widely acknowledge that Stellera (and also the other paper plants as Daphne and Wikstroemia) is a poisonous plant, which reared animals do not eat, and notably that its fragrance is poisonous and can provoke headaches to people. Actually it seems that some of its popular denominations include the term $m g o$, "head", which might be related to this plant quality.

3 Stellera chamaejasme L. is a perennial species that has a stout, thick, branched or not woody rhizome, many clustered erect and unbranched stems $(20-50 \mathrm{~cm}$.) The globose terminal inflorescence bears many fragrant flowers. The calyx is white, yellow or reddish purple. Flowering season spans from April to June. The fruit is a conic drupe. It grows in sunny and dry slopes, sandy places, between $2600-4200$ in Gansu, Qinghai, Sichuan, TAR, and Yunnan. It is also diffused in Bhutan, Mongolia, Nepal, in several Chinese provinces, and Russia (Wu et al. 2007, 13: 250.). According to Polunin and Stainton (1989: 356) it grows in Uttar Pradesh (now Uttarakhand), India. 


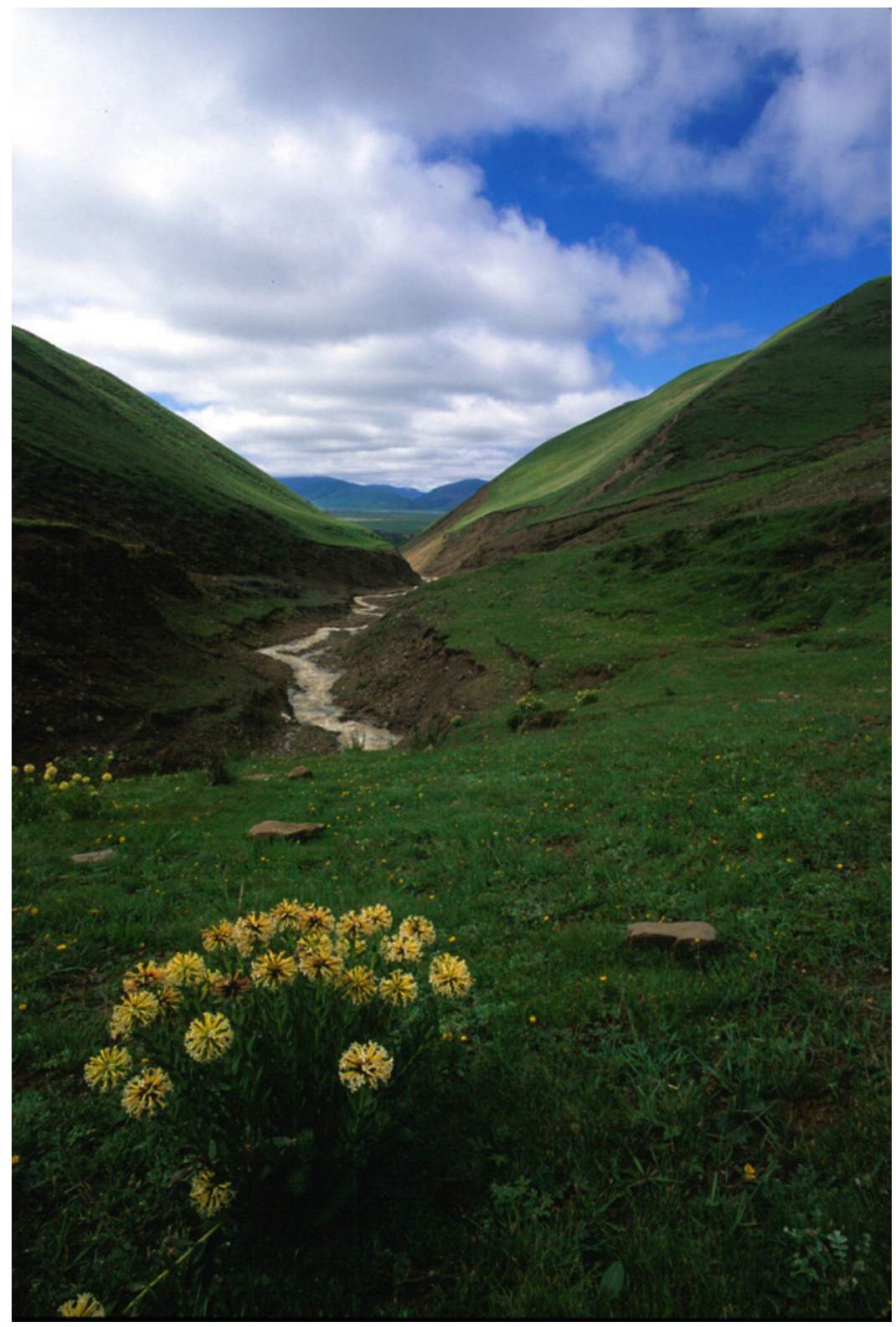

FIGURE 22.1 Stellera chamaejasme, Lithang, Sichuan, China.

PHOTOGRAPH: ALESSANDRO BOESI, 2000. 
Concerning paper production in Li thang, Duncan (1964: 73-74) reported that in the 1920s, "Litang monastery has a set of blocks for the Kagyur but printing has ceased due to the expense of paper since bark must be brought from a distance of two or more day's journey." It is interesting to note that this information may contrast with my observations, particularly if the term 'bark' refers here to the root bark of Stellera chamaejasme. At Li thang and surrounding area at the time of my fieldwork this plant abundantly grew on south facing slopes and thus could be easily collected as a source material for paper-making. It may put forward that, when Duncan visited Li thang, the plant used to produce paper was not Stellera chamaejasme, but another species of the Thymelaeaceae family, possibly Daphne or Wikstroemia, or both of them, some species of which likely grow in Lithang County and other parts of western Sichuan. ${ }^{4}$ For reasons that I explain below, at that time Stellera chamaejasme could not grow as abundantly as today or could even be rare at Li thang. Also, local people might have deemed Stellera chamaejasme less valuable than the other available local plants suitable for making paper and that it was more convenient to collect the raw material from the bark of the stems of other Thymelaeaceae species growing in areas two or more day's journey distant than obtaining it from Stellera chamaejasme roots, the extraction of which from the soil represents a more difficult procedure. Helman-Ważny and Van Schaik (2013:2) reported that this material requires a longer time for processing, and an extra step in the papermaking process.

'Gyur med tshe brtan, another traditional doctor working in Li thang and coming from gLing ka skyid, a rong valley located in Li thang County, came to my help by reporting that in his homeland a plant named shog shing did grow, which was different from re lcag pa, and that in the past was used to make paper. This plant might belong to Daphne or Wikstroemia species. Edgeworthia gardneri, another important paper plant in Tibet and Himalayan regions, does not thrive in this area (Wu et al. 2007, 13: 247).

A few recent studies support the hypothesis that at that time paper plants were possibly collected two or more day's journey from Li thang. Research has shown that Stellera chamaejasme is a pest plant, having the ability of successfully competing with other species and particularly quickly colonizing

4 According to the Flora of China (Wu et al. 2007, 13: 215-245), Wikstroemia leptophylla, W. scytophylla, W. capitatoracemosa, Daphne papyracea, D. aurantiaca, D. tangutica, and others are diffused in the Tibetan areas of western Sichuan. Yet at the present stage of research except for a few, we do not known which of these species have been used or not for making paper, for example D. tangutica and W. capitatoracemosa, and we do not know whether they grow or not in Lithang County. 
degraded pasturelands. Stellera is able to synthesize and secrete in the soil secondary metabolites that prevent some other plant species to grow. Notably Hui (2011) showed that Stellera can exert allelopathic inhibition on several Fabaceae and grasses through water leaching, residue decomposition, and root exudates. ${ }^{5}$ Recent investigations have also shown that mainly from the 1960 s onwards pasture overexploitation owing to increases in cattle and sheep numbers has been a diffuse phenomenon over the Tibetan plateau. According to Sun et al. (2009) this phenomenon is particularly relevant in alpine meadows on the eastern Tibetan regions, which have been overgrazed during the last several decades and are suffering serious invasion of Stellera chamaejasme. Also Klein et al. (2007) suggested that climate warming in the area may have increased production of this non-palatable forb. Thus it is almost sure that in the past Stellera chamaejasme was not as diffused as it is at present in Tibet. This has been shown (Sun et al. 2009) in Zung chu County (Songpan County, rNga ba Tibetan and Qiang Autonomous Prefecture, Sichuan Province, PRC), a region that has been heavily grazed in the past few decades. According to local informants in the 1960s Stellera chamaejasme was not diffused there whereas today it abundantly grows in the area, notably on flat valleys and south-facing slopes. ${ }^{6}$

These data possibly imply that in the past Stellera chamaejasme was not as abundantly spread as it is today also in Li thang and surrounding area, and that local people used to collect it or other Thymelaeaceae species in other parts of their territory as Duncan reported.

5 According to Hui (2011), the role that Stellera chamaejasme has in grassland degradation is significant owing to its competitive encroachment on several plant species. Wang Hui showed that Stellera released allelochemicals provoked allelopathic inhibitions on the four Fabaceae Medicago sativa, Onobrychis viciifolia, Coronilla varia, and Melilotus suaveolens, and at a lesser extent on the six Poaceae Agropyron cristatum, Agropyron mongolicum, Elymus dahuricus, Psathyrostachys perinnes, Bromus inermis, and Lolium perenne. This study demonstrated that the allelopathic inhibition of Stellera roots was particularly significant, and that it enhanced with the increase of roots biomass. The inhibitory effect of Stellera stems and leaves was relatively weak, but when the amount of stems and leaves increased, it also significantly inhibited the growth of the four kinds of legumes, and augmented its allelopathic effects on forages. See also Zhou et al., 1998.

6 According to Sun et al. 2009 one of the outcomes of Stellera chamaejasme spread in this area is displacement of the dominant palatable Kobresia and Poa species, while its toxicity prevents it from being eaten by yaks (Liu et al. 2004). For these reasons, Stellera spread threatens productivity, conservation, and ecological sustainability in wide range of meadows and grasslands on the Tibetan Plateau of China (Xing et al. 2002; Liu et al. 2004). 
The recent Stellera chamaejasme spread over the Tibetan plateau also entails that, when considering the amount of source material for paper-making that was available in the past, we cannot rely on the present abundance and distribution figures of this species. This might in part explain why the Tibetan manuscript brought from central Tibet during the imperial period and sealed in Dunhuang caves have been produced from Daphne and Edgeworthia fibres (Helman-Ważny and Van Schaik 2013). It is worth noting that the choice of using or not using Stellera chamaejasme might have been also influenced by the habit of this species, which may vary according to altitude and climate. For example, near Shigatse (TAR) I observed specimens that were tinier and more slender that the ones growing in many eastern Tibetan regions, so possibly offering less raw material for paper-production.

Daphne species ${ }^{7}$ grow in several Tibetan cultural regions, notably in southern and eastern Tibetan plateau, and also on the southern side of the Himalayan Range. These areas are dominated by deep, forested valleys often run by big rivers, and host lush vegetation. Among the different Daphne species diffused in these regions, some have been reported to represent raw material for paper making as Daphne sureil, ${ }^{8}$ D. bholua,${ }^{9}$ D. aurantiaca, ${ }^{10}$ and

The Daphne genus includes shrubs or subshrubs, evergreen or deciduous, with mostly alternate, sometimes opposite leaves. The inflorescence, usually terminal, has pink or yellow, rarely mauve flowers with campanulate, cylindric, or slightly funnel-shaped calyx. The fruit is a succulent berry or dry and leathery, sometimes enclosed by persistent calyx, sometimes naked, usually red or yellow. In China $5^{2}$ Daphne species are present, of which 41 are endemic (Wu et al. 2007, 13: 230-245).

8 Daphne sureil is an evergreen shrub to $2.5 \mathrm{~m}$., the bark is greyish brown, the branches ascending and tomentose. Leaves are alternate, lanceolate to oblong-lanceolate, $5^{-13} \times$ ${ }^{1.6-5} \mathrm{~cm}$. Inflorescences are usually terminal, flower calyx is white with green base; Flowering season spans from October to November. Drupe is orange-red, ovoid, ca. $15 \times$ $10 \mathrm{~mm}$. It grows in dense montane forests; $1800-2100(-2800) \mathrm{m}$. in TAR, [Bangladesh, Bhutan, NE India, E Nepal] (Wu et al. 2004, 13: 241).

9 Daphne bholua is a evergreen or deciduous shrub, creeping or erect, $1-4 \mathrm{~m}$ tall. Branches are brownish, becoming dark brown suffused with purple. Leaves are alternate, clustered at stem apex, narrowly elliptic or oblong-lanceolate $\left(3 \cdot 5^{-17} \times\right)$. Flowers are fragrant with purplish red or red calyx. Flowering season spans from January to March. Drupe is black, ovoid, $7-8 \times$ ca. $5 \mathrm{~mm}$. It grows in forests, $1700-3500 \mathrm{~m}$., in Sichuan, TAR, northwest Yunnan [Bangladesh, Bhutan, India, Myanmar, Nepal] (Wu et al. 2007, 13: 244).

10 Daphne aurantiaca is an evergreen shrub up to $1.2 \mathrm{~m}$ tall with the main branches reddish to dark brown, often prostrate. Leaves are obovate, ovate, or elliptic, glabrous, max $2.3 \times$ $1.2 \mathrm{~cm}$. It has terminal inflorescences, $2-5$-flowered. The flowers are fragrant with deep yellow to orange calyx. Drupe is brownish yellow, ellipsoid, $3-5 \times 2-3 \mathrm{~mm}$. The flowering season spans from May to June. It grows in forests, shrubby slopes, often on ledges and faces of limestone cliffs $(2600-3500 \mathrm{~m}$.) in southwest Sichuan and northwest Yunnan (Wu et al. 2007, 13: 235). 
D. retusa ${ }^{11}$ (Chamling 1996: 44), some others might have been used for this purpose and only further research may allow us to assess this.

Edgeworthia gardneri ${ }^{2}$ thrives between 1000 and $2500-3500$ metres in eastern TAR and northwestern Yunnan in the same environmental condition of Daphne, and it also grows on the southern slopes of Himalaya in India, Bhutan, and Nepal where it has been used for paper making as well. Out of the 4 Edgeworthia species present in China, only one, Edgeworthia gardneri, grows on the Tibetan plateau, so it must be this plant to have been used in Tibet to make paper.

Wikstroemia ${ }^{13}$ canescens $^{14}$ is a very interesting plant that mainly grows in southern TAR. Jim Canary (Paper Road Tibet Project) ${ }^{15}$ reported that he found

11 Daphne retusa is an evergreen shrub, 0.4-1.5 $\mathrm{m}$ tall, densely branched. Leaves are alternate, usually clustered at apices of branches; leaf blade is oblong, oblong-lanceolate, or obovate-elliptic $(1.4-7 \times 0.6-1.4 \mathrm{~cm})$. The inflorescence is terminal, usually several flowered. Flowers are fragrant with calyx purplish red with paler purple-pink or white lobes. Drupe is red, subglobose or ovoid, 6-8 mm. The flowering season spans from April to May. It grows in shrubby or herbaceous slopes; 3000-3900 m., in Gansu, Hubei, Qinghai, Shanxi, Sichuan, TAR, Yunnan [Bhutan, north India (Assam, Punjab), Kashmir, Nepal] (Wu et al. 2007, 13: 238).

12 Edgeworthia gardneri Meisner is a small tree to 3-4 metres tall with a brownish red stem. It has elliptic-lanceolate pubescent leaves, inflorescence 30-50-flowered, with flowers borne in round clusters. Calyx exterior is densely white sericeous and the 4 lobes yellow. Flowering season spans from late winter to early spring. Drupe is ovoid, densely sericeous. It grows in forests, moist places, 1000-2500(-3500) metres, in east TAR, northwest Yunnan [Bhutan, India, N Myanmar, Nepal] (Wu et al. 2007, 13: 247).

13 The genus Wikstroemia includes shrubs or subshrubs, occasionally small trees or rarely a herbaceous perennial (W. linoides), evergreen or deciduous. These species have usually terminal and subterminal inflorescence, flowers are yellow or green, less often purplish, red or white, cylindrical or tubular, sometimes slightly funnel-shaped. The fruit is a succulent berry or rather dry. This genus includes about 70 species, of which 49 (43 endemic) are present in China. It is worth noting that the separation of Wikstroemia from the genus Daphne is problematic. "Features such as leaf arrangement, inflorescence type, and flower colour are all clearly paralleled within the two genera and are of no diagnostic value, although they are mentioned in most keys to these genera." and even concerning the nature of the hypogynal disk, "there are species where the interpretation of the structure of the disk is difficult" (Wu et al. 2007, 13: 215).

14 Wikstroemia canescens is a shrubs $1.6-2 \mathrm{~m}$ tall, often much branched toward apex. Branches are purple-black, turning greyish brown, pubescent. Alternate leaves are greenwhitish, lanceolate, $2.5-5.5 \times 0.8-2.5 \mathrm{~cm}$, Inflorescences are many, terminal, and axillary, elongating into racemes after anthesis, $4^{-10}$-flowered; Calyx is yellow, ca. $15 \mathrm{~mm}$. Drupe is dry. Flowering season is in autumn. Wikstroemia canescens grows on shrubby slopes, among rocks, 1000 to $2800(-3500)$ metres in TAR [Afghanistan, Bangladesh, India, Japan, Nepal, Pakistan] (Wu et al. 2007, 13: 225).

See Paper Road Tibet Project: tslingo.tripod.com/paper_road.htm 
in a village near sKyems stong in Dwags po, to the southeast of Lhasa, an old man who showed him an area where he collected samples of a six to eight foot shrub locally named skyems shing, identified as Wikstroemia canescens, a species that grows on three mountains near sKyems stong, and was used for producing skyems shog, 'Kyemdong paper'. A recent Tibetan publication points out that this was traditionally considered the paper of the highest quality and it was used among other things for the production of Tibetan money (Tsundru 2010). Bertsch (1996: 8) quoted another source (Rhodes 1992: 93) that mentions the bark of a tree called 'Shogshing' (shog shing), and the place of collection at 'Kemdong' (skyems stong). The information was given in Calcutta by the Tibetan official Ngawang Tsultrim Kesang in 1927. Huber (1999: 262) in his book The Cult of the Pure Crystal Mountain reported that, "raw materials for papermaking were regularly carried by corvée from Chayül Dzong to Chösam, from where the Tsariwa had to deliver them to Kyemdong Dzong." This corroborates the accounts that sKyems stong was an important centre for paper collection and production. Also Stein (1986: 9) wrote that in Dwags po Daphne laureola was collected to manufacture Tibetan paper (dwags shog, 'Dwags po paper'). Yet this species does not grow in Asia and so this plant likely belongs to another Daphne or Wikstroemia species, or to Edgeworthia gardneri.

According to Khartasia, ${ }^{16}$ Wikstroemia canescens also grows in Yunnan province and it is used for making paper also in primarily Tibetan inhabited areas as Deqen (bDe chen) and Gyalthang (rGyal thang, Zhongdian) in Deqen Tibetan Autonomous Prefecture. Khartasia (Table 1) reported that besides Wikstroemia canescens other 13 Wistroemia species grow in Yunnan. Among these, 6 thrive in its northwestern areas (W. delavayi, W. leptophylla, W. canescens, W. lichiangensis, W. scytophylla, and W. lamatsoensis), ${ }^{17}$ and three of them (W. delavayi, W. canescens, and W. lichiangensis) have been used by Naxi to make Dongba paper. ${ }^{18}$ Since these species certainly grow in Tibetan cultural areas, it is possible that also local Tibetans have used them for paper-making. According to

16 The database Khartasia combines historical and technological information on components of the papermaking plants, papermaking manufacturing, paper names and characteristics of papermaking fibres. This information comes from literature surveys carried out in collaboration with partner institutions in China, Korea and Japan. See: www. khartasia-crcc.mnhn.fr/en/content_en/wikstroemia-canescens-wall-ex-meisn

17 The Flora of China (Wu et al. 2007, 13: 215-229) confirms this.

18 According to Khartasia, the paper produced by Naxi "is also called 'Baidi' from the name of the village (Baishuitai or 'white water terraces' Shangri-La) which is native Dongba culture. The tradition traces the production of paper by the Naxi in the Yuan Dinasty (1280-1368) but the first Dongba texts date from 1668 (www.khartasia-crcc.mnhn.fr/en/ content_en/wikstroemia-canescens-wall-ex-meisn). 
the Flora of China (Wu et al. 2007, 13: 224-225) other two Wikstroemia species grow in TAR: W. lungtzeensis and W. capitatoracemosa, which might also have been used for paper production. Further research is needed to verify this.

TABLE 22.1 Wikstroemia species used for paper-making in Yunnan according to Khartasia

Botanical species $\quad$ Place of growth

Wikstroemia canescens Wallich ex

Meisner

Wikstroemia lichiangensis W. W. Smith

Wikstroemia delavayi Lecomte
Shrubby slopes, among rocks; $1000-2800$ $(-3500)$ m. TAR [Afghanistan, Bangladesh, India, Japan, Nepal, Pakistan].

Forests; 2600-3500 m. SW Sichuan, NW Yunnan.

Valley forests, shrubby or limestone areas; 2000-2700 m. Sichuan, Yunnan

I have already mentioned above that Stellera chamaejasme is a poisonous plant. Also, Tibetans designate Daphne paper as dug shog, 'poison paper'. Several species of the Thymelaeaceae family share this significant feature: being poisonous, they are not attacked by insects, worms, and small animals, an additional quality that makes them an excellent source material for paper-making. The toxicity of Thymelaeaceae species has been well established for humans as well as for several higher animal species. Toxic manifestations may be divided into those observed when the plant materials are taken internally and those seen when such materials are contacted externally. Concerning the Thymelaeaceae species that Tibetans have used to make paper recent studies have shown that Wikstroemia canescens has antibiotic properties. People from Parbati Valley of Kullu District in Himachal Pradesh (India) use this plant as pesticidal (Sharma and Samant 2014: 96), and in the rural areas of Nepal this plant is traditionally used as an abortifacient (Gyawali et al. 2010: 205). Different root extracts of Stellera chamaejasme showed antimicrobial activity against several microorganisms, and particularly against three bacteria, and twelve phytopathogenic fungi (Lin et al. 2009; Bai et al. 2012). Other studies have reported pesticidal and acaricidal activity (Wang et al. 2002; Shi et al. 2004). Daphne bholua is used to treat intestinal worms in Sikkim Himalaya (Panda and Misra 2010: 186), it showed antibacterial, antifungal, antiprotozoal, and antiviral activity (Goel et al. 2002). From Edgeworthia gardneri substances having antimicrobial and antibiotic activity have been isolated (Gao et al. 2008; Chakrabarti et al. 1986). 
Codicological studies, examination of paper fibres from ancient manuscripts and books, information available on Tibetan written sources, accounts from travellers, explorers, and missionaries, data from botanical studies, and recent research in the field, indicate that a few species belonging to the Thymelaeaceae family have represented the most important source material for paper-making in Tibet. So far, among the Thymelaeaceae, the following species have been identified as raw materials used in Tibetan cultural regions: Edgeworthia gardneri, Daphne sureil, D. bholua, D. aurantiaca, D. retusa, Wikstroemia canescens, and Stellera chamaejasme. These plants grow in the areas inhabited by Tibetan people, and can be easily collected. Yet in Tibetan regions do grow other Daphne and Wikstroemia species, which may also have been used for this purpose.

Thymelaeaceae is a dicotyledonous family including $5^{2}$ genera and more than $75^{\circ}$ species, among them small trees, shrubs, and herbaceous plants. Some of these species share a particular feature: their phloem or bast, the plant nutrient conductive tissue, includes very strong fibres. These fibres are long, narrow, and supportive cells, which provide tension strength without limiting flexibility, and render the bark of these plants a valuable material for the manufacture of high-quality paper. In fact their stems (and roots) are supple and difficult to break and may be used as a substitute for string. The poisonousness of several of these species, as stated above, is an additional feature that makes them particularly suitable for making paper.

The other plant species that have also been used for paper production in Tibet include paper mulberry, Broussonetia papyrifera (Moraceae), ${ }^{19}$ which thrives in south-eastern Tibetan Autonomous Region (TAR), Yunnan and Sichuan Provinces, and since ancient times has been cultivated in China for paper manufacture. According to Khartasia ${ }^{20}$ Broussonetia papyrifera has been used for paper-making in southeast TAR and this agrees with the findings of Helman-Ważny and Van Schaik (2013, see below). Meisezahl et al. (1961: 15-18)

19 Broussonetia papyrifera is a tree $10-20 \mathrm{~m}$. tall with flowers always produced on leafy stems. Leaves are ovate to elliptic-ovate, spirally arranged, simple or $3-5$-lobed on young trees. The male and female flowers are borne on separate plants, the female flowers being greenish and held in round heads, the male plants bearing catkins. The edible fruits are orange-red, round or pear-shaped. It grows in many Chinese provinces, among them in Gansu, Sichuan, southeast TAR, and Yunnan (Wu et al. 2003, 5: 26-27; http:// khartasia-crcc.mnhn.fr/en/content_en/broussonetia-papyrifera-l-lher-ex-vent). B. papyrifera prefers sub-humid warm, sub-tropical monsoon climates in moist forests, and, at a lesser extent, temperate climates, and it grows up to 2100 metres. 
examined a four-layered Tibetan paper and found that the outer layers were made from Broussonetia fibres and bamboo. ${ }^{21}$

According to informants birch bark, mainly from Betula utilis (stag pa shing, gro ga), which grows in southern and eastern TAR, and also Betula alnoides (stag pa shing), has been used in Tibet and high Himalayan valleys. ${ }^{22}$ The bark of birch, according to Ketzer (1993: 21), has been used in Tibet until the 17th century only for special occasion like short texts. It was the inner bark of the tree that was used for writing. After peeling off the tree, it was dried. Oil was then applied to it and it was polished. Finally the birch bark was cut to a suitable size. Besides B. utilis and B. alnoides 12 other birch species are diffused over the Tibetan plateau. Additional study is needed to assess whether some among them have also been used for paper making.

The origin of Tibetan paper is still unclear. The main reference study for this subject is the one conducted by Helman-Ważny and Van Schaik (2013). As they reported, this issue has taken political overtones: the Chinese claim that paper was introduced from China whereas some Tibetan scholars argue that it originated in the ancient kingdom of Zhang zhung. Another topic of discussion, which is related to the subject of this article, is whether the original Tibetan paper was made from Daphne/Edgeworthia species or/and from Stellera chamaejasme. In the 8th century the Chinese already had a long experience in paper making and have probably used "a variety of raw fibres that included the rags of hemp, flax (ropes) and ramie (known as "Chinese grass"), bark of mulberry, bamboo and rattan, rice and wheat straw, and many other types of grass depending on the region of production." (ibidem: 2). Some of these plants as Broussonetia papyrifera (see above) also grow in Tibetan cultural regions.

Helman-Ważny and Van Schaik (2013) specifically investigated the earliest extant Tibetan paper from the manuscripts discovered in the caves of Dunhuang in Gansu Province (China). They examined paper fibres and combined their results with codicological, palaeographical, and textual information. The examination included 63 samples taken from 50 manuscripts of the Stein Collection. Helman-Ważny and Van Schaik found that the majority of manuscripts were rag paper primarily composed of Boehmeria sp. (ramie) and Cannabis sp. (hemp), sometimes with the addition of other fibres such as Corchorus sp. (jute) or Broussonetia sp. (paper mulberry). This type

Phyllostachys, Pleioblastus, Bambusa, Dendrocalamus, Sinocalamus and Chimonobambusa species, according to Maoyi (1999). for paper-making, certainly B. utilis that thrives in south and east Tibetan Autonomous Region. 
of paper and the technology to produce it showed that these manuscripts were made in Dunhuang or in other parts of China. Yet 6 samples were produced by using plant fibres from Thymelaeaceae, specifically Daphne sp. or Edgeworthia sp. Among these last works, one was evidently produced in central Tibet during the imperial period, and another likely came from the same area. None of the Tibetan manuscripts known to be made in Dunhuang was made from Thymelaeaceae fibres. Also a letter found in Miran possibly coming from central Tibet was made from Daphne or Edgeworthia, mixed with paper mulberry, and other 12th-13th century Tibetan manuscripts brought from Tibet to Kharakhoto by Tibetan monks were produced from Daphne or Edgeworthia. Interestingly Helman-Ważny and Van Schaik found that methods of production and textual evidence suggest that other manuscripts were brought to Dunhuang from Tibet. Yet, these texts, again dating from the first half of the ninth century, were not made from Thymelaeaceae fibres, but from Broussonetia, sometimes possibly mixed with hemp or Morus sp., mulberry.

This study essentially showed that the manuscripts likely coming from central Tibet were made from Daphne and/or Edgeworthia plant fibres, and that, at the present state of research, it seems that Thymelaeaceae family plants were not used in Central Asia or China. Tibetans had likely developed the techniques for making paper during the imperial period from as early as the first half of the ninth century. The raw material for this technology were mainly plants belonging to the Thymelaeaceae family, particularly Daphne and Edgeworthia, which occur widely in the Himalayas, and in southern and southeastern Tibetan regions. It is surprising that evidence of the use of Stellera chamaejasme roots was not found in any Dunhuang manuscript (at this stage of research). People from central Tibet might have preferred to use Edgeworthia and Daphne rather than Stellera chamaejasme, the roots of which are difficult to obtain, and possibly because, as recent studies (see above) have shown, this plant was not so abundantly diffused in the past as it is today, and only in the last decades has been rapidly spreading in many areas where it was rare before. So, as Helman-Ważny and Van Schaik stated: "root paper was probably only made where other plant sources were unavailable" such as in the Tibetan plateau regions where Edgeworthia and Daphne do not grow, notably in the higher and drier part of it, actually covering the majority of its extension, and cannot be imported. The date when this practice began remains to be determined (the earliest known examples of Stellera paper go back to the 1oth/11th century, see Helman-Ważny and Pasang Wangdu in this volume). Thus it seems that Daphne spp., Edgeworthia sp. (E. gardneri since it is the only species of this genus that grows in Tibet), and Broussonetia sp. (B. papyrifera, for the same 
reason as above) were used for papermaking in early Tibet. The authors conclude claiming that given the patterns of plant distribution in Tibet, it is likely that the primary type of paper used in central and perhaps western Tibet was made from Thymelaeaceae species.

Edgeworthia and Daphne thrive up to 3500 and more in typically Tibetan cultural areas where they have been easily available to local Tibetan people. Edgeworthia grows in eastern TAR and in northwestern Yunnan, and not also in Sichuan, Gansu and Qinghai Provinces as Daphne (Wu et al. 2007 13, 247-248). Broussonetia papyrifera grows at lower altitude (up to $2100 \mathrm{~m}$.) in some areas of southeast TAR, in Sichuan and Yunnan. According to Ju et al. (2013: 7) Broussonetia papyrifera thrives in Deqen (bDe chen Tibetan Autonomous Prefecture, Yunnan), a Tibetan cultural area, which below 2500 metres includes subtropical and warm temperate climate.

Interestingly the data of Trier (1972: 245-246), although obtained in Nepal where environmental conditions and plant availability are different (and by examining a number of samples that is not representative), agree with those of Helman-Ważny and Van Schaik. Trier analyzed 22 paper samples from books written in Tibetan and identified 16 samples as being made entirely from Daphne bholua, two samples were exclusively made from Edgeworthia gardneri, three were a mixture from Daphne bholua and Edgeworthia gardneri, and only one was made from Stellera chamaejasme.

Further research is needed to assess whether also Wikstroemia species, and particularly $W$. canescens, were used in ancient Tibet, as it is likely. It is interesting to note that properly distinguishing Daphne and Wikstroemia species is difficult through the examination of both their morphological features (see footnote 13) and bast fibre anatomic structures (Meisezahl et al. 1960: 300). Thus some of the specimens so far studied and identified as Daphne might belong to Wikstroemia.

The majority of paper plants have been used in Tibetan medicine, and are often named with specific other designations; several medical texts mention their employ for paper production but only in passing. Thus I have examined some Tibetan materia medica treatises composed in pre-modern Tibet to tease out this information. This study is not exhaustive and more work, also on other texts, is necessary to give a comprehensive view on the concept of these plants as material to make paper according to Tibetan medical texts. 
Some modern Tibetan materia medica and recent research publications include the botanical identification of Tibetan medicinal plants. Yet it must be highlighted that these identifications may be valid only for specific regions. One of the main features of Tibetan materia medica, particularly concerning medicinal plant identification, is that it exhibits strong variability. In the vast area inhabited by Tibetan people, which exhibits geographical, climatic, ecological, and floristic differences, medical practitioners have to select their medicinal agents in contrasting environmental settings. Variability in materia medica identification may also be related to practitioners' education and to the peculiar ways local medical traditions practise medicine. Thus in different areas homonyms of Tibetan medicinal plant designations often correspond to different botanical species (Boesi 2004: 297-304; Salick et al. 2006). This explains why the identification of paper plants may vary according to different sources.

So far I have found that, according to medical texts, the following medicinal plants have been used as raw material for paper production: ar nag, ar skya, re lcag pa, sngon bu, and dug srad. The first four designations most likely indicate the principal paper plants that have been used in Tibet. According to modern Tibetan materia medica re lcag pa corresponds to Stellera chamaejasme, ar nag to Daphne aurantiaca and Wikstroemia canescens, ar skya to Daphne aurantiaca, and sngon bu to a few Campanulaceae species. The fifth denomination, dug srad, indicates a substitute: Oxytropis ochrocephala or/and Astragalus. strictus.

\subsection{Ar nag, ar skya}

According to one of the most important Tibetan materia medica, which was composed in 1727 by De'u dmar dge bshes bstan 'dzin phun tshogs (1994: 236), ar nag is considered as a type of a ga ru, "it has flowers and leaves similar to the ones of re lcag pa" (Stellera chamaejasme), and thus it likely belongs to the Thymelaeaceae family, "it has yellow flowers and it is a type of shog shing ["paper wood"] since its skin is suitable for making paper". ${ }^{23}$ The Mongol doctor rJam dpal rdo rje (1971: folio 111) in his illuminated work on Tibetan medicinal substances possibly compiled in the first half of the 19th century, reported the same information given by De'u mar dge bshes bstan 'dzin phun tshogs. The modern Tibetan materia medica composed by dGa' ba'i rdo rje (1998: 164-165) describes the ar nag as a type of shog shing and identifies it as both Daphne

23 me tog re lcag pa'i dbyibs ji lta ba la/ me tog kha dog ser ba shing lpags shog bu 'chos nyen pas shog shing rigs yin la/ 


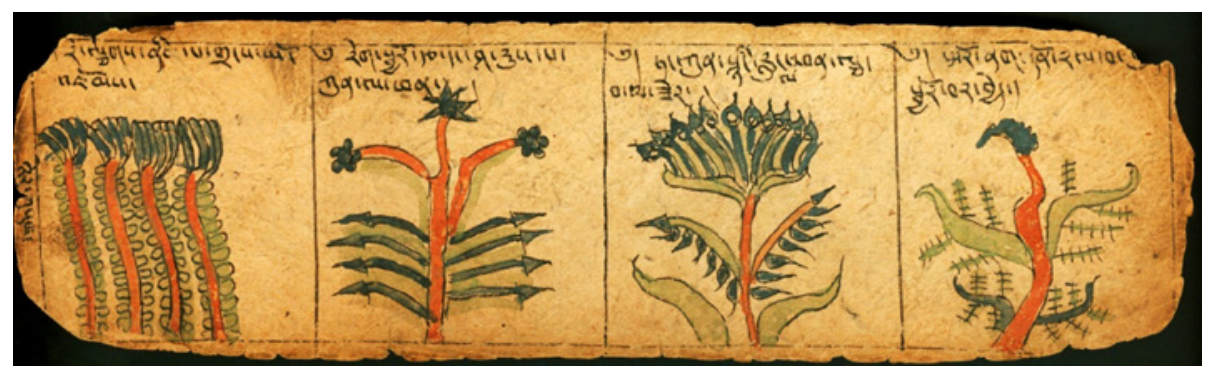

FIGURE 22.2 Folio $(23 R)$ from a Tibetan materia medica manuscript (author and title unknown). In the first section from the left, the author illustrated re lcag pa (Stellera chamaejasme) and noted its medical properties. The caption says: "re lcag nim pa completely heals cold diseases." (Boesi 2015).

aurantiaca and Wikstroemia canescens. The former identification is also given by Zhongguo kexueyuan xibei gaoyuan shengwu yanjiusuo (1991: 452-453) ${ }^{24}$ for a type of a ga ru. Both $D$. aurantiaca and $W$. canescens have yellow flowers as the ones of Edgeworthia gardneri, another paper plant.

According to the Vaidurya sngon po (sDe srid Sangs rgyas rgya mtsho 1982: 253), the commentary to the rGyud bzhi (g.Yu thog yon tan mgon po 1992) written by the regent Sangs rgyas rgya mtsho in 1687-88, the type of a ga ru that can be used as a source material for paper-making is not the black type, but the 'light colour', ar skya, type. sKar ma chos dpel (1993: 94), author of a modern Tibetan materia medica, agrees with Sangs rgyas rgya mtsho and identifies this plant as Daphne aurantiaca.

Interestingly Gabrish (1990: 49) reported that one of his informants mentioned the plant ar bo gra bo as one of the raw materials used for the production of banknote paper. The term ar bo gra bo, 'multicoloured ar bo', may be related to ar nag/ar skya, being a synonym or indicating another type of this plant.

\subsection{Re lcag pa}

According to De'u dmar dge bshes bstan 'dzin phun tshogs (1994: 290) "with the root (of re lcag pa) paper is made". $25 \mathrm{rJam}$ dpal rdo rje (1971: folio 150) wrote that: "with the single segment white root (of re lcag pa) the paper of dBus was

\footnotetext{
24 This text aims at identifying and describing from a modern scientific point of view medicinal substances used in Tibetan medicine.

25 (re lcag) rtsa bas shog bu byed payin/
} 
made". ${ }^{26}$ So in the first half of the 19th century this plant was used in central Tibet for this purpose. In the materia medica compiled by the physician Cha har dGe bshes blo bzangs tshul khrims (1740-1810) (2007: 79-80) in the section devoted to re lcag $p a$, the author informed us on the part of the root used to make paper: "it is said that the white bast is suitable to make paper, and it is also called sho gu bzo rung". ${ }^{27}$

\section{3 sNgon bu}

Tibetan medical treatises describe a plant named sngon bu that most likely corresponds to a Thymelaeaceae species. According to De'u dmar dge bshes bstan 'dzin phun tshogs 18th century materia medica (1994: 287) sngon bu is also designated as shog shing pa. So we may presume that it was used as a raw material for paper-making. This plant is also described in the treatise Gso dpyad rin po che'i 'khrungs dpe bstan pa (g.Yu thog yon tan mgon po 2006: 109). This is, according to Tibetan tradition, a very old text of Indian origin that was translated under the supervision of the scholar Shantigarbha in the 8th century. When describing the plant named sngon bu, its author wrote: "with the assembled bark [of sngon bu] one can get paper". ${ }^{28}$ Thus sngon bu has likely been used for paper-making for long time, and to my knowledge this work might represent the most ancient written source to mention that a plant collected in Tibet has been used for paper-making. Yet according to modern Tibetan materia medica its botanical identification corresponds to Cyananthus sherriffii (dGa' ba'i rdo rje, 1998: 195), a slender herbaceous species growing in southern TAR in alpine meadows and thickets (3200-5000 m.) (Wu et al. 2011, 19: 510), to C. argenteus $^{29}$ and to C. incanus (Karma chos dpel, 1993: 208), the former thrives in northwest Yunnan (2800-4300 m.) (Wu et al. 2011, 19: 509), the latter in south Qinghai, west Sichuan, east TAR, and northwest Yunnan (bDe chen, rGyal thang) (2700-5300 m.) (Wu et al. 2011, 19: 509). These species, which belong to the Campanulaceae family, have certainly not been used as raw material for paper-making. Yet since Tibetan medical treatises see sngon bu as the designation that indicates one of the plants that were used in southern Tibetan valleys to produce paper, it may put forward that this plant likely corresponds to other species, possibly to the Thymelaeaceae Daphne,

\footnotetext{
26 rtsa ba dkar po rkang gcig bas dbus shog byed pao/

27 bar shun dkar po la sho gu bzo rung ces kyang zer ba zhig la byed do/I would like to thank Professor Elena de Rossi Filibeck for revising the translation of this passage.

28 shun pa bsdus pas shog bu 'byung/

29 Synonym of Cyananthus longiflorus Franchet.
} 
Wikstroemia, or Edgeworthia. Zur mkhar ba blo gros rgyal po (1989:528) comes to our help in his treatise rGyud bzhi'i 'grel pa mes po'i zhal lung, compiled in the 16th century. In the section devoted to describing sngon bu he commented: "Concerning sngon bu, the real one is the shog shing pa that grows in Dwags po and Kong po." So in these regions does thrive a type of sngon bu, which is different from the sngon bu recognized in other Tibetan areas. This is also corroborated by the doctor Cha har dGe bshes blo bzang tshul khrims (1740-1810) (2007: 79), who wrote that "concerning the real sngon bu, it is the shog shing that grows in Dwags po",30 and it is noteworthy that he adds that "if one does not find it, it is claimed that re lcag pa is a suitable substitute". ${ }^{31}$ This indicates that re lcag and sngon bu share similar features, may be strongly related, and that the latter possibly belongs to the Thymelaeaceae family.

Interestingly the authors of another medical treatise (Yid lhung 'Jam dbyangs et al. 1986) composed in the 18th century, the students of the famous Si tu pan chen chos kyi 'byung gnas (1700-1774), gave important information on the identification of sngon bu (folio 84). They claim that two types of sngon bu are recognized according to the medical tradition: ${ }^{32}$ the byang lugs tradition recognizes a type that has a silver blue flower whereas the zur lugs tradition identifies sngon bu with a plant called shog shing a ga ru, with which bast paper is made. ${ }^{33}$ Zur mKhar ba blo gros rgyal po was a disciple of Zur mKhar ba mnyam nyid rdo rje, the founder of Zur lugs tradition. That is why according to him, the real sngon bu is the one from Dwags po with which paper is made. It is worth noting that the differences between the two medical traditions mentioned above likely reflected the different ecological and epidemiological conditions of the regions where they have been practised. The Byang tradition was mainly rooted in the northern plateau while the Zur tradition originated in Tibetan southern valleys as Dwags po (see Meyer 1995: 116).

$30 \quad$ sngon bu dngos ni dwags po'i yul du skye ba’i shog shing yin lal

31 ma rnyed na re lcag gis tshab rung bar'dod do/

32 Several medical traditions propounded by learned masters have developed during the history of Tibetan medicine, with their own medical lineages, followers and treatises. Among these, the Byang (see Hofer 2007) and Zur traditions, named after their founding lineages, the famous practitioners Byang bdag rnam rgyal grags bzang (1395-1475) and Zur mKhar ba mnyam nyid rdo rje (1439-1475) respectively, were established in Tibet in the $15^{\text {th }}$ century. They differed only in minor issues, such as the location of a few channels and vital points of the body, identification of medicinal substances and concept of medical formulae (see Meyer 1995).

sngon bu ni byang lugs pas me tog sngon po dngul'od can byed kyang/sur lugs [?] shun pas shog bu byed pa'i shog shing a ga ru ser ba de'i bar shun mdzed/ 
Thus it is plausible to claim that the 'real' sngon bu from Dwags po described in Tibetan medical treatises corresponds to Daphne, Wikstroemia, or Edgeworthia species, which grow in this region and have been the only plants used there by Tibetans for making paper (besides Broussonetia).

\subsection{Dug srad}

According to Hildegard Diemberger, who worked on Tibetan paper and text printing in southern Tibet, one of her informants, a local traditional doctor, affirmed that in case of lack of shog gu me tog, the root of a plant called srad $m a$ was used as substitute. The informant also reported that this paper plant is poisonous and that its fragrance provokes headache. According to Diemberger this plant's botanical identification corresponds to Oxytropis sp.

De'u dmar dge bshes bstan 'dzin phun tshogs (1994: 395) mentioned a type of srad ma, named dug srad ('poisonous srad'), which, according to the text 'Khrungs bkod, has tender aggregate leaves and whitish flowers. It grows in lower areas, has a fragrance and toxic properties, since it can kill snakes and render cattle confused when they eat it, the fumigation of which is used to paralyse evil spirits, and its roots are used to make paper. According to sKar ma chos 'phel (1993) materia medica, dug srad corresponds to Astragalus strictus, ${ }^{34}$ and according to dGa' ba'i rdo rje (1998: 311) to Oxytropis ochrocephala. ${ }^{35}$ Both species are poisonous and are reported to be a serious hazard to Tibetan livestock causing poisoning and even death (Hao Lu et al. 2014; Wu Chenchen et al. 2014; Zhao Meng-Li et al. 2011). Both species are present over Tibetan cultural regions, the former thrives at higher altitude $(3000-5600)$ than the latter $(1800-4500)$.

34 Astragalus strictus (Fabaceae) is a herbaceous species 8-30 $\mathrm{cm}$ tall, hairy, with pinnate leaves $(4-7 \mathrm{~cm})$ and $8-12$ pairs of elliptic leaflets. Inflorescences are arranged in racemes up to 20 -flowered. Flowers are pale pinkish to purple; Legumes have a $0.5^{-1} \mathrm{~mm}$ beak. It grows in alpine steppic grasslands, stony slopes, 3000-5600 m. in Qinghai, Sichuan, Xinjiang, TAR, Yunnan [Bhutan, India, Kashmir, Nepal] (Wu et al. 2010, 10: 387).

35 Oxytropis ochrocephala (Fabaceae) is a tuft-forming herbaceous species ${ }^{10-56} \mathrm{~cm}$ tall. Stems are erect or sprawling. Leaves are pinnate 3-19 cm, 11-39-foliolate. Racemes are compact, 8-14-flowered or more; Calyx is cylindrical and corolla yellow. Legume has inflated body, its beak incurved at apex. It grows in grasslands, weedy slopes and alpine meadows, 1800-4500 m., in Gansu, Hebei, Nei Mongol, Ningxia, Qinghai, Sichuan, Xinjiang, and TAR (Wu et al. 2010, 10: 474). 
'Jam mgon kong sprul blo gros mtha' yas (1813-1899), well known 19th century Buddhist master from Khams, devoted to paper-making a section of his encyclopaedic work on Buddhism and Buddhist culture, the Treasury of Allpervading Knowledge ('Jam mgon kong sprul blo gros mtha' yas 1982). In book six part one (Ibidem vol. 2: 204-359) 'Jam mgon kong sprul blo gros mtha' yas described the different plants that are used for paper manufacture and claimed that different qualities of paper are produced in Tibet according to the materials with which they are made: superior, average, and inferior materials. He also stated that each Tibetan region may have a different quality of paper, produced by using specific materials and manufacturing techniques.

A plant designated shog ldum dung lo ma is indicated as representing the best paper plant. Tibetan medical treatises, for example the 18th century Shel gong shel phreng (De'u dmar dge bshes bstan 'dzin phun tshogs 1994: 290), mention the term shog ldum as a synonym for re lcag pa, yet the terms shog ldum dung lo ma and dung lo ma ("conch shell leaves"), to my knowledge, do not appear. At the popular level, shog ldum is used as a general term to designate paper plants. So shog ldum dung lo ma might indicate a paper plant having leaves that are similar to a conch shell. 'Jam mgon kong sprul blo gros mtha' yas went on describing the place of growth of this plant, which includes a type of soil, notably dark soil ( sa nag), ${ }^{36}$ the presence of shug pa (Juniperus sp., Cupressus sp., Playticladus sp.) (Boesi 2004: 180), and a ground free from boulders and rocks. The author also described a yellow flowered variety of shog ldum dung lo ma growing in red sandy soil interspersed with slabs of stones, which is difficult to cook since it is hard. He added that when the bark is thick and harbours insects, it is deemed to be of inferior quality.

The botanical identification of shog ldum dung lo ma must correspond to one species (or more than one) of the Thymelaeaceae family. As stated above, Tibetans use the term shog ldum (as well as shog shing) to generally designating paper plants, and the ones that are deemed to be of good quality always correspond to Thymelaeaceae species.

The description of shog ldum dung lo ma by 'Jam mgon kong sprul blo gros mtha' yas may help us in its identification, particularly when he mentioned the existence of a yellow-flowered variety. This most likely implies that the flower colour of the latter is different from the one of the "standard" shog ldum

36 According to informants from Li thang County (Sichuan, China), sa nag indicates a dark soil, which is soft, of good quality, and over which abundant vegetation grows. 
dung lo $m a$, which must not be yellow. If so, the botanical identification of shog ldum dung lo ma cannot correspond to paper plants as Wikstroemia canescens, which is seen as one of the best raw materials to produce high quality paper in South-eastern Tibet, and Edgeworthia gardneri, since these two plant species have yellow or yellowish-green flowers. This might corroborate the idea that this information likely refers to paper plants collected and used in sDe dge principality and adjacent regions in today northern Sichuan, where both Wikstroemia canescens and Edgeworthia gardneri do not grow. It also seems that 'Jam mgon kong sprul blo gros mtha' yas spent most of his life in this area (yet only an in-depth examination of his biography can confirm this point). Also, sDe dge, dPal yul, and dKar mdze in northern Khams were important centres for the production of paper (Weber 2007: 111), 'Jam mgon kong sprul blo gros mtha' yas was an expert of Tibetan pharmacopoeia ('Jam mgon kong sprul blo gros mtha' yas 2013: 1), and possibly knew well, collected and saw paper plants since they are also used as medicines. Had the author obtained this information on paper in northern Khams, it might be speculated that other Daphne species having white, red, and purplish flowers, growing in Sichuan, and that Tibetans see as important raw materials for manufacturing paper, might correspond to shog ldum dung lo ma. Daphne bholua and Daphne retusa represent two possible candidates: the former grows in TAR, Sichuan and Yunnan Tibetan areas, and on the southern side of the Himalayan range, the latter is present in Qinghai, Sichuan, TAR, and Yunnan. Another option might be Daphne sureil, which grows in TAR and on the southern side of the Himalayan range, but not in Sichuan. Only further research may confirm these assumptions. Concerning the denomination of this plant, it is interesting to note that since these Daphne species may have glossy glabrous leaves, Tibetans could have seen them as recalling conch shells, the surface of which is smooth and shiny.

When 'Jam mgon kong sprul blo gros mtha' yas wrote that the average quality source material is obtained from a ga ru, he most likely meant the variety of it called shog shing ar nag (see above), which, according to him, is particularly suitable for thick paper used in writing books. Finally the worst material comes from réu lcag (re lcag pa) (Stellera chamaejasme, see above). According to 'Jam mgon kong sprul blo gros mtha' yas, the hard paper obtained from it may be used for writing letters, but it is not good for books, and the plants that grow in soft and sandy soil, and in soft dark soil areas are excellent. This idea can be explained by considering that, when the soil is softer and allows the plants to grow abundantly as the "dark soil" does, Stellera roots get bigger and offer more raw materials for paper making. 
Paper plants classifications from the Tibetan perspective may vary and do not imply that in different areas the botanical identifications correspond. People have had to adapt to local environmental conditions and available materials, as 'Jam mgon kong sprul blo gros mtha' yas reported. So considering for example Central Tibet and northern Khams areas, the best and average plant materials to manufacture paper may have been obtained from different species. Concerning re lcag pa, since it grows in most of Tibetan regions were paper has been traditionally produced, its botanical classification is certain, but its quality may have been perceived differently according to local traditions.

\section{Discussion}

According to information from travellers' accounts, recent research, Tibetan medical treatises, and my fieldwork, it is possible to devise a preliminary list of some of the plant species that Tibetans have used for making paper (Table 22.2). This list is certainly not exhaustive since botanical studies have shown that several other Daphne and Wikstroemia species grow over the Tibetan plateau: some of them might also have been used for producing paper. In addition, paper-plant identification may not be simple given that some species as Daphne and Wikstroemia are difficult to be distinguished one from the other upon both morphological traits and fibre structure (Wu et al. 2007, 13: 215; Meisezahl et al. 1960: 300).

As it has been show above, the majority of Tibetan paper-plants belong to the Thymelaeaceae family, and notably to Daphne, Stellera, Edgeworthia, and Wikstroemia species. The other plants have most likely had minor impact on paper production in Tibet. They include Broussonetia papyrifera (Moraceae), Betula utilis and B. alnoides (Betulaceae), and either Oxytropis ochrocephala and/or Astragalus strictus (Fabaceae). These two species have been only used as substitutes and among the Tibetan books that have been so far examined, none has been found to have been made from their bast fibres. 
TABLE 22.2 Preliminary List of Raw Material Sources for Traditional Paper in Chinese Tibetan regions

\begin{tabular}{lll}
\hline Botanical name $\quad$ Local name & Forest type and altitửe
\end{tabular}

$$
\begin{array}{lll}
\text { Edgeworthia gardneri } & \text { shog shing, shog gu me tog } & \text { Forests, moist places; } \\
\text { Meisner } & 1000-2500(-3500) \text { m. E } \\
& \text { TAR, NWYunnan [Bhutan, } \\
& \text { India, N Myanmar, Nepal]. }
\end{array}
$$

Daphne aurantiaca Diels shog shing, shog gu me tog, Forests, shrubby slopes, arnag, ar skya often on ledges and faces of limestone cliffs; $2600-3500$ m. SW Sichuan, NW Yunnan

Daphne sureil W. W. Smith shog shing, shog gume tog Dense montane forests; \& Cave 1800-2100(-2800) m. TAR, Bangladesh, Bhutan, NE India, Nepal.

Daphne bholua Buchanan- shog shing, shog gu me tog Forests; 1700-3500 m. Hamilton ex D. Don

Sichuan, TAR, NWYunnan [Bangladesh, Bhutan, India, Myanmar, Nepal]

Daphne retusa Hemsle shog shing Shrubby or herbaceous slopes; 3000-3900 m. Gansu, Hubei, Qinghai, Shanxi, Sichuan, TAR, Yunnan

Daphne spp. shog shing, shog gu me tog TAR, Yunnan, Sichuan, Gansu, Qinghai

Stellera chamaejasme L. re lcag pa, shog ldum $p a$, Sunny and dry slopes, sandy shogshing pa, mgo re lcag places; 2600-4200 $\mathrm{m}$. re, ra ma rwa co, mgo na ra, Gansu, Hebei, Heilongjiang, mgo bo rolgdangs Henan, Jilin, Liaoning, Nei Mongol, Ningxia, Qinghai, Shanxi, Sichuan, Xinjiang, TAR, Yunnan [Bhutan, Mongolia, Nepal, Russia]. 


Botanical name Local name Forest type and altitude

\begin{tabular}{lll}
\hline Wikstroemia canescens & $\begin{array}{l}\text { shog shing, shog gu me tog, } \\
\text { skyems shing, ar nag }\end{array}$ & $\begin{array}{l}\text { Shruby slopes, among } \\
\text { Wallich ex Meisner }\end{array}$ \\
& m. TAR, NWYunnan,
\end{tabular}

Afghanistan, Bangladesh, India, Nepal, Pakistan.

Wikstroemia spp. Astragalus strictus shog shing, shog gu me tog, srad, dug srad

TAR, NW Yunnan. SE TAR. Alpine steppic grasslands, stony slopes; 300o-5600 m. Qinghai, Sichuan, Xinjiang, TAR, Yunnan [Bhutan, India, Kashmir, Nepal].

\begin{tabular}{|c|c|c|}
\hline Oxytropis ochrocephala & srad, dug srad & $\begin{array}{l}\text { Grasslands, weedy slopes } \\
\text { and alpine meadows; } \\
\text { 1800-4500 m. Gansu, } \\
\text { Hebei, Nei Mongol, Ningxia, } \\
\text { Qinghai, Sichuan, Xinjiang, } \\
\text { TAR. }\end{array}$ \\
\hline $\begin{array}{l}\text { Broussonetia papyrifera (L.) } \\
\text { Vent }\end{array}$ & & $\begin{array}{l}\text { Sub-humid warm, sub-tropi- } \\
\text { cal monsoon climates in } \\
\text { moist forests, temperate } \\
\text { climates up to } 21 \text { oo metres. } \\
\text { Gansu, Sichuan, SE TAR, } \\
\text { Yunnan, and many Chinese } \\
\text { provinces. }\end{array}$ \\
\hline Betula utilis D. Don & stag pa shing, gro ga & $\begin{array}{l}\text { Temperate broad-leaved } \\
\text { forests; 2500-380o m. } \\
\text { Gansu, Hebei, Ningxia, } \\
\text { Qinghai, Shaanxi, W } \\
\text { Sichuan, E and S TAR, NW } \\
\text { Yunnan [Afghanistan, } \\
\text { Bhutan, India, Nepal] }\end{array}$ \\
\hline $\begin{array}{l}\text { Betula alnoides Buchanan- } \\
\text { Hamilton ex D. Don }\end{array}$ & stag pa shing & $\begin{array}{l}\text { Fujian, Guangxi, Hainan, } \\
\text { Hubei, Sichuan, S Yunnan, } \\
\text { 70o-210o m. [Bhutan, } \\
\text { India, Myanmar, Nepal, } \\
\text { Thailand, Vietnam] }\end{array}$ \\
\hline
\end{tabular}


Examining the distribution over the Tibetan plateau of the Thymelaeaceae species, one notices that the majority thrive in southern and eastern regions in the so-called rong areas, which Tibetans see as deep valleys cut by strong rivers, hosting lush forests, where temperature is milder, and land is suitable for agriculture. These areas roughly correspond to southeast and east TAR, northwest Yunnan, western Sichuan, and some areas of Qinghai and Gansu Provinces. A few of these species are also distributed in other parts of China and/or on the southern side of the Himalaya. Daphne aurantiaca, only growing in southwest Sichuan and in northwest Yunnan Chinese Provinces, is nearly endemic to Tibetan cultural regions. It should be noted that only Stellera chamaejasme is able to thrive at high altitude over 4000 metres, and that in some areas of the Tibetan Plateau, as sDe dge in Sichuan (Duncan 1964: 64; Dongfa 2010: 78-79) and Nang chen in southwest Qinghai (Teichman 1922: 107), it has been used as main source material for paper-making. Besides Stellera chamaejasme, among the Thymelaeaceae that have been possibly used to make paper, Daphne retusa (3000-3900 m.), D. tangutica (1000-3800 m.), D. rosmarinifolia $(2500-3800 \mathrm{~m}$.$) , and D$. giraldi $(1600-3100 \mathrm{~m}$.) grow in Qinghai up to 3900 metres (Wu et al., 2007, 13: 230-345). Yet, as D. rosmarinifolia, they mainly grow is southeast Qinghai, far from Nang chen.

So Daphne and Wikstroemia species, and Edgeworthia gardneri, have been mainly collected in southern and eastern Tibet whereas Stellera chamaejasme roots were found on the higher plateau areas. According to available information, in central and west Tibet different raw materials for paper production have been imported. At rGyal rtse (Waddell 1905: 226) both Stellera chamaejasme and Daphne/Wikstroemia/Edgeworthia were used. At Lhasa according to rJam dpal rdo rje (see above) re lcag pa was used, and travel accounts as the one by Beetham ${ }^{38}$ indicate that Daphne and/or Wikstroemia and/or Edgeworthia were sent to the capital from southern Tibet. All these materials were used alone or mixed in paper manufacture.

On the basis of the examination of Tibetan books and other information it is reasonable to think that Daphne and Wikstroemia species, and Edgeworthia gardneri have represented the most important raw materials for paper production in Tibet. Some areas in south-east Tibet, as sKyems stong in Dwags po (Paper Road Tibet Project; ${ }^{39}$ Huber 1999: 262), have represented important centres for paper-plants collection and paper production. These plants, as Wikstroemia canescens, have been sought after because of their high quality (Tsundru 2010) and local people used them to produce paper and to pay taxes

38 See The Bentley Beetham Collection http://www.bentleybeetham.org/index.php.

39 See Paper Road Tibet Project: tslingo.tripod.com/paper_road.htm. 
to the central Tibetan government (Huber, ibidem). Tibetans would likely prefer to use Daphne/Wikstroemia/Edgeworthia than Stellera chamaejasme: its roots are difficult to be extracted from the soil, require a longer time for processing, and an extra step in the papermaking process. In addition this plant was likely not as diffused in the past over Tibetan regions as it is today. Yet Stellera chamaejasme was important in plateau areas, particularly when distant from the areas of collection of the other Thymelaeaceae.

The tradition of paper making in Tibet has been preserved up to the present time. Stellera chamaejasme is used in a few printing houses and paper making centres in places such as sDe dge, Lhasa, and sNye mo (TAR), whereas in southern TAR and in the Himalayan Valleys, Daphne/Wikstroemia/Edgeworthia species represent the main source material as it happens in Bhutan (see Table 22.3). As transportation has dramatically improved in the last few years, the mixing of different species has become easier and often one place may produce different types of paper with different ingredients.

TABLE 22.3 Raw Material Sources for Traditional Paper in Bhutan (Chamling 1996: 44).

\begin{tabular}{lll}
\hline Botanical name & Local name & Forest type and altitude
\end{tabular}

\begin{tabular}{|c|c|c|}
\hline $\begin{array}{l}\text { Edgeworthia gardneri } \\
\text { Meisner }\end{array}$ & $\begin{array}{l}\text { De shing }(\mathrm{Dz}) \text {, Shogo shing } \\
\text { balingmeen (Sh), Kagate, } \\
\text { Argayle }(\mathrm{N})\end{array}$ & $\begin{array}{l}\text { Wet, sub-tropical forest; } \\
1,670-2,400 \mathrm{~m} .\end{array}$ \\
\hline Daphne involucrata Wall. & $\begin{array}{l}\text { Seti barwal, Chhota, } \\
\text { Argaule, Bimbiri }(\mathrm{N})\end{array}$ & $\begin{array}{l}\text { Mixed broad-leaved forest; } \\
1,200-2,000 \mathrm{~m} \text {. }\end{array}$ \\
\hline $\begin{array}{l}\text { Daphen bholua Buchanan- } \\
\text { Hamilton ex D. Don }\end{array}$ & $\begin{array}{l}\text { De shing }(\mathrm{Dz}) \text {, Shogo shing } \\
(\mathrm{Sh}) \text {, Shugu shing }(\mathrm{Sh}), \\
\text { Kagate, Argayle }(\mathrm{N})\end{array}$ & $\begin{array}{l}\text { Evergreen oak, blue pine, } \\
\text { spruce, hemlock and fir } \\
\text { forests; } 1,980-3,400 \mathrm{~m} \text {. }\end{array}$ \\
\hline $\begin{array}{l}\text { Daphne sureil W. W. Smith } \\
\text { \& Cave }\end{array}$ & $\begin{array}{l}\text { Kagate, Argayle, Bhale and } \\
\text { Kagate }(\mathrm{N})\end{array}$ & $\begin{array}{l}\text { Warm, broad-leaved and } \\
\text { evergreen oak forests; } \\
1,220-2,130 \mathrm{~m} \text {. }\end{array}$ \\
\hline Daphne retusa Hemsle & & $\begin{array}{l}\text { Rocky hillsides and wet } \\
\text { ravines; 3,700-4,200 m. }\end{array}$ \\
\hline D. ludlowii D. G. Long \& Rae & & $\begin{array}{l}\text { Mixed rhododendron, } \\
\text { hemlock, and spruce forests; } \\
3,35^{0}-3,5^{80} \mathrm{~m} \text {. Endemic to } \\
\text { Bhutan. }\end{array}$ \\
\hline
\end{tabular}

Source: Flora of Bhutan (1991).

$(\mathrm{Dz})=$ Dzongkha $(\mathrm{Sh})=$ Sharchop-kha $(\mathrm{N})=$ Nepali 


\section{References}

Agrawal, O. P. 1984. Conservation of Manuscripts and Paintings of South-east Asia. London: Butterworths.

Bai, X., Cheng, J., Liang, W., Ma, L., Liu, Y., Shi, G. and Wang, Y. 2012. Antifungal Activity of Extracts by Supercritical Carbon Dioxide Extraction from Roots of Stellera chamaejasme L. and Analysis of Their Constituents Using GC-MS. Information Technology and Agricultural Engineering Advances in Intelligent and Soft Computing 134, 653-62.

Bertsch, W. 1996. A survey of Tibetan paper Currency (1912-1959). Bulletin of Tibetology $3,3-22$.

Boesi, A. 2004. Le savoir botanique des Tibétains: perception, classification et exploitation des plantes sauvages. $\mathrm{PhD}$ dissertation, Université de la Méditerranée, Marseille.

2015. Piante medicinali del Tibet. Un antico manoscritto di scienza della guarigione. Roma: ISMEO, Scienze e Lettere.

Chakrabarti, R., Das, B. and Banerji, J. 1986. Bis-coumarins from Edgeworthia gardneri. Phytochemistry 25(2), 557-558.

Chamling, K. D. 1996. Traditional Paper, Essential Oils, Rosin and Turpentine. In NonWood Forest Products of Bhutan, 43-47. Bangkok: The Food and Agriculture Organization of the United Nations, Rap Publication.

Chandra, L. (ed). 1971. An Illustrated Tibeto-Mongolian Materia Medica of Ayurveda of rJam dpal rdo rje of Mongolia. New Delhi: International Academy of Indian Culture.

Chenchen, W., Wenlong, W., Xiaoxue, L., Feng, M., Dandan, C., Xiaowen, Y., Shanshan, W., Pengshuai, W., Hao, L. and Baoyu, Z. 2014. Pathogenesis and preventive treatment for animal disease due to locoweed poisoning. Environmental Toxicology and Pharmacology 37, 336-47.

sDe srid Sangs rgyas rgya mtsho, 1982. Gso ba rig pa'i bstan bcos sman bla'i dgongs rgyan rgyud bzhii gsal byed be daura sngon po’i malila ka. Lhasa: Bod ljongs mi dmangs dpe skrun khang.

De'u dmar dge bshes bstan 'dzin phun tshogs, 1994. Shel gong shel phreng. Dharamsala: Tibetan Medical and Astro Institute.

Dongfa, X. 2010. Categories, Features and Social Backgrounds of the Existing Wood Blocks for Printing in China. In S. M. Allen, L. Zuzao, C. Xiaolan and J. Bos (eds) The History and Cultural Heritage of Chinese Calligraphy, Printing, and Library Work. Munich: De Gruyter Saur.

Duncan, M. H. 1964. Customs and superstition of Tibetans. London: The Mitre Press. dGa' ba'i rdo rje, 1998. 'Khrungs dpe dri med shel gyi me long. Beijing: Mi rigs dpe skrun khang.

Gabrish, K. 1990. Geld aus Tibet. Winterthur: Departement für Kulturelles Rikon Tibet Institute. 
Gao, Z, Maloney, D. J., Dedkova, L. M. and Hecht S. M. 2008. Inhibitors of DNA polymerase beta: activity and mechanism. Bioorganic \& Medicinal Chemistry 16(8), 4331-40.

Goel, A. K., Kulshreshtha, D.-K., Dubey, M. P. and Rajendran S. M. 2002. Screening of Indian plants for biological activity: Part XVI. Indian Journal of Experimental Biology 40: 812-827.

Grierson, A. J. C. and Long, D. G. 1991. Flora of Bhutan including a record of plants from Sikkim and Darjeeling: Volume 2, Part 1. Edinburgh: Royal Botanic Garden.

Grong khyer lha sa khreng kon chus 'ja' tshon mi rigs lag rtsal zhib 'jug 'phel rgyas lte gnas (eds). 2010. Bod shog bzo rtsal myur skyob dang 'phel rgyas skor. Beijing: Mi rigs dpe skrun khang. Beijing: 2010.

Gyawali, R., Tuladhar, L., Shakya, R., Shrestha, R., Shah, S. and Shrestha, T. M. 2010. Phytochemical studies and in vitro activity of Wikstroemia canescens. Journal of Tropical Medicinal Plants 11(2): 205-06.

Helman-Ważny, A. and Van Schaik S. 2013. Witnesses for Tibetan Craftsmanship: Bringing Together Paper Analysys, Palaeography and Codicology in the Examination of Earliest Tibetan manuscripts. Archaeometry 55(4): 707-741.

Hofer, T. 2007. Preliminary Investigations into New Oral and Textual Sources on Byang lugs - the 'Northern School' of Tibetan medicine. In Soundings in Tibetan Medicine Historical and Anthropological Explorations, edited by M. Schrempf, 373-410. Leiden: Brill Academic Publishers.

Huber, T. 1999. The Cult of the Pure Crystal Mountain: Popular Pilgrimage and Visionary Landscape in Southeast Tibet. Oxford: Oxford University Press.

Hui, W. 2011. The Study on Stellera Chamaejasme Allelopathic Way and Strength. Master's thesis, Inner Mongolia Agricultural University, Hohhot.

'Jam mgon kong sprul blo gros mtha' yas, 1982. Shes bya kun khyab. Beijing: Mi rigs dpe skrun khang.

Jamgon Kongtrul Lodro Taye, 2013. Treasury of Knowledge: Book Six, Parts One and Two: Indo-Tibetan Classical Learning and Buddhist Phenomenology, edited by Gyurme Dorje. Boston: Shambala Publications.

Ji, Y. H., Luo, P., Pei, S. J. and Xu, J. C. 20oo. Traditional utilization of Chinese 'chellera' (Stellera chamaejasme L.) in northwest Yunnan, China. Ethnobotany 12: 23-26.

Ju, Y., Zhuo, J., Liu, B. and Long, C. 2013. Eating from the wild: diversity of wild edible plants used by Tibetans in Shangri-la region, Yunnan, China.Journal of Ethnobiology and Ethnomedicine 9, 28.

Karma chos 'phel, 1993. Bdud rtsi sman gyi 'khrungs dpe legs bshad nor bu'i phreng mdzes. Lhasa: Bod ljongs mi dmangs dpe skrun khang.

Klein, J. A., Harte, J. and Zhao, X.-Q. 2007. Experimental Warming, not Grazing, Decreases Rangeland Quality on the Tibetan Plateau. Ecological Applications 17(2), 541-557. 
Liu, Y., Long, R. and Yao, T. 2004. Research progress on Stellera chamajasme L. in grassland. Pratacultural Science 21, 55-61 (in Chinese with English abstract).

bLo bzang tshul khrims, 2007. Cha har dge bshes kyi sman yig byu ru do shel dang rin chen do shel. Beijing: Mi rigs dpe skrun khang.

Lu, H., Cao, D. D., Ma, F., Wang, S. S., Yang, X. W., Wang, W. L., Zhou, Q. W. and Zhao B. Y. 2014. Characterisation of locoweeds and their effect on livestock production in the western rangelands of China: a review. The Rangeland Journal 36(2): 121-131.

Ma, L., Kang, X., Huang, Y., Hou, D. and Hou, T. 2009. Antimicrobial activity of root extracts of Stellera chamaejasme L. from China. World Applied Sciences Journal 6(5): 664-68.

Maoyi, F. 1999. Bamboo resources and utilization in China. In A. N. Rao and V. R. Rao (eds) Bamboo - Conservation, Diversity, Ecogeography, Germplasm, Resource Utilization and Taxonomy. Proceedings of training course cum workshop 10-17 May 1998, Kunming and Xishuanbanna, Yunnan, China. Rome: International Plant Genetic Resources Institute. http://www.bioversityinternational.org/fileadmin/ bioversity/publications/Web_version/572/ch24.htm.

Meisezahl, R. O., Harder-Steinhäuser, M. and Jayme, G. 1961. Alttibetische Handschriften im Reiss-Museum, Mannheim. Libri (Copenhagen) 11(1): 1-48.

1960. Über den Derge Tanjur der ehemaligen Preussischen Staatsbibliothek. Libri (Copenhagen) 10(4): 292-306.

Meyer, F. 1995. “Theory and Practice of Tibetan Medicine." In Oriental Medicine. An Illustrated Guide to the Asian Arts of Healing, edited by J. Van Alphen and A. Aris, 109-43. London: Serindia.

Panda, A. K. and Misra, S. 2010. Health Traditions of Sikkim Himalaya. Journal of Ayurveda \& Integrative Medicine 1(3): 183-189.

Polunin, O. and Stainton, A. 1989. Flowers of the Himalaya. New Delhi: Oxford University Press.

Rhodes, N. G. 1992. Tibetan forgeries made in Calcutta. The Numismatic Chronicle 152, $89-96$.

Salick, J., Byg, A., Amend, A., Gunn, B., Law, W. and Schmidt, H. 2006. Tibetan Medicine Plurality. Economic Botany LX (3): 227-253.

Sharma, P. and Samant, S. S. 2014. Diversity, Distribution and Indigenous uses of medicinal plants in Parbati Valley of Kullu district in Himachal Pradesh, Northwestern Himalaya. Asian Journal of Advanced Basic Sciences 2(1): 77-98.

Shi, G. L., Liu, S. Q., Cao, H., Zhao, L. L., Li, J. and Li, S. Y. 2004. Acaricidal activities of extracts of Stellera chamaejasme against Tetranychus viennensis (Acari: Tetranychidae). Journal of Economic Entomology 97(6): 1912-16.

Stein, R. A. 1986. La Civiltà Tibetana. Milano: Einaudi.

Sun, G., Luo, P., Wua, N., Qiu, P. F., Gao, Y. H., Chen, H. and Shi, F. S. 20og. Stellera chamaejasme L. increases soil $\mathrm{N}$ availability, turnover rates and microbial biomass 
in an alpine meadow ecosystem on the eastern Tibetan Plateau of China. Soil Biology \& Biochemistry 41, 86-91.

Teichman, E., 1922. Travels of a consular officer in Eastern Tibet. Cambridge: Cambridge University Press.

The Bentley Beetham Collection. http://www.bentleybeetham.org/index.php.

Trier, J. 1972, Ancient paper of Nepal: result of ethno-technological field work on its manufacture, uses and history - with technical analyses of bast, paper and manuscripts. Copenhagen: Jutland Archaeological Society Publications.

Turner, S. 1800. An account of an embassy to the Court of the Teshoo Lama in Tibet. London: Bulmer.

Waddell, A. 1905. Lhasa and Its Mysteries. London: J. Murray.

Wang, Y., Zhang, G., Xu, H. and Chu, S. 2002. Biological activity of extracts of Stellera chamaejasme against five pest insects. Insect Science 9(3): 17-22.

Wu, Z. G., P. H. Raven and H. Deyuan (eds) 1995 present. Flora of China. Beijing: Science Press, St. Louis: Missouri Botanical Garden Press. http://flora.huh.harvard.edu/ china/mss/edit.htm.

Xing, F., Song, R., Qi, B., Guo, J. 2002. Analysis to the interspecific association of Stellera chamaejasme population and other main plant species in Cleistogenes squarrosa steppe. Acta Prataculturae Sinica 11, 46-51 (in Chinese with English abstract).

Yid-lhun 'Jam-dbyan்s, Nag-dban-rgyal, Bkra-śis-'bum, and Lha-ru Kun-khyab. 1986. Nus pa rkyan sel gyi sman ngo gsal byad. Instructions for recognizing various medicinal plants according to the methods taught by Si-tu pan-chen Chos gyi-'byun-gnas (1700-1774) by his students. Reproduced from a rare manuscript from the library of Ye-śe-don-ldan. Smanrtsis Shesrig Spendzod, Volume 145. Leh: Tashigang.

g.Yu thog yon tan mgon po. 1992. Bdud rtsi snying po yan lag brgyad pa gsang ba man ngag gi rgyud. Lhasa: Bod ljongs mi dmangs dpe skrun khang.

Zhao, M.-L., Gao, X. and Han, B. 2011. Locoweed Poisoning in the Native Grasslands of China. The International Journal of Poisonous Plant Research 1(1): 41-46.

Zhongguo kexueyuan xibei gaoyuan shengwu yanjiusuo (ed) 1991. Zangyao zhi. Xining: Qinghai Renmin.

Zhou, S., Huang, Z., An, R., 1998. Preliminary study on the allelopathy of Stellera chamaejasme. Grassland of China 52-55 (in Chinese with English abstract).

Zur mkhar ba blo gros rgyal po. 1989. Rgyud bzhi'i 'grel pa mes po'i zhal lung. Beijing: Krung go'i bod kyi shes rig dpe skrun khang. 